\title{
Social network of family caregivers of disabled and dependent patients*
}

\author{
REDE SOCIAL DE CUIDADORES FAMILIARES DE PACIENTES COM INCAPACIDADES E \\ DEPENDÊNCIA
}

\section{RED SOCIAL DE CUIDADORES FAMILIARES DE PACIENTES CON DISCAPACIDAD Y DEPENDENCIA}

\section{Cintia Hitomi Yamashita ${ }^{1}$, Jaqueline Correia Gaspar ${ }^{2}$, Fernanda Amendola ${ }^{3}$, Márcia Regina Martins Alvarenga ${ }^{4}$, Maria Amélia de Campos Oliveira $^{5}$}

\begin{abstract}
Cross-sectional study that used the Social Network Index and the genogram to assess the social network of 110 family caregivers of dependent patients attended by a Home Care Service in São Paulo, Brazil. Data were analyzed using the test $U$ of Mann-Whitney, Kruskal-Wallis and Spearman correlation. Results were considered statistically significant when $p<0,05$. Few caregivers participated in activities outside the home and the average number of people they had a bond was 4,4 relatives and 3,6 friends. Caregivers who reported pain and those who had a partner had higher average number of relatives who to trust. The average number of friends was higher in the group that reported use of medication for depression. Total and per capita incomes correlated with the social network. It was found that family members are the primary caregiver's social network.
\end{abstract}

\section{DESCRIPTORS}

Disabled persons

Family

Caregivers

Home nursing

Family relations

Social support

\section{RESUMO}

Objetivo: Avaliar a rede social de 110 cuidadores familiares de pacientes dependentes atendidos por um Serviço de Assistência Domiciliária no município de São Paulo. Método: Estudo transversal, que utilizou o Social Network Index e o genograma. Os dados foram analisados pelos testes $U$ de Mann-Whitney, Kruskal-Wallis e correlação de Spearman. Resultados: Foram considerados estatisticamente significativos quando $p<0,05$. Poucos cuidadores participavam de atividades extradomiciliares e o número médio de pessoas com quem mantinham vínculo era de 4,4 familiares e de 3,6 amigos. Cuidadores que referiram dor no corpo e aqueles que possuíam companheiro apresentaram maior número médio de parentes em quem confiar. A média de amigos foi superior no grupo que referiu uso de medicamentos para depressão. Rendas total e per capita mostraram correlação com a rede social. Conclusão: Verificou-se que os familiares são a principal rede social do cuidador.

\author{
DESCRITORES \\ Pessoas com deficiência \\ Família \\ Cuidadores \\ Assistência domiciliária \\ Relações familiares \\ Apoio social
}

\begin{abstract}
RESUMEN
Estudio transversal que utiliza el Índice de la Red Social y el genograma para evaluar la red social de los 110 cuidadores familiares de enfermos dependientes atendidos por un servicio de cuidados en el hogar, en São Paulo. Los datos fueron analizados por las pruebas de Mann-Whitney, Kruskal-Wallis y la correlación de Spearman. Los resultados se consideraron estadísticamente significativos cuando $p<0,05$. Pocos cuidadores participaban en actividades fuera del hogar y el número promedio de personas con las cuales tenían vínculo fueran 4,4 personas de la familia y 3,6 amigos. Los que informaron dolor en el cuerpo y los que tenían una pareja tenían mayor número medio de familiares en que confiar. El número medio de amigos fue mayor en el grupo que informó el uso de medicación para la depresión. Los ingresos totales y per cápita se correlacionaron con la red social. Se encontró que los miembros de la familia son la principal red social del cuidador.
\end{abstract}

\section{DESCRIPTORES}

Personas con discapacidad

Familia

Cuidadores

Atención domiciliaria de salud

Relaciones familiares

Apoyo social

\footnotetext{
* From the dissertation "Assessment of the network and social support of family caregivers of disabled and dependent patients", School of Nursing, University of São Paulo; 2013. ${ }^{1}$ Doctoral candidate of the Nursing Graduate Program, School of Nursing, University of São Paulo, São Paulo, SP, Brazil. 2 Doctoral candidate of the Nursing Inter-units Program, School of Nursing of Ribeirão Preto, University of São Paulo, São Paulo, SP, Brazil. ${ }^{3}$ Professor, School of Nursing, Hospital Israelita Albert Einstein, São Paulo, SP, Brazil. ${ }^{4}$ Adjunct professor, Nursing course, Universidade Estadual de Mato Grosso do Sul, Dourados, MS, Brasil. ${ }^{5}$ Full professor, Department of Nursing in Collective Health Care, School of Nursing, University of São Paulo, São Paulo, SP, Brazil.
} 


\section{INTRODUCTION}

The Home Care Program, created in 2002 by the Ministry of Health by means of Law 10.424, was proposed as an alternative to hospitalization ${ }^{(1)}$. This is an important care model in this period of demographic and epidemiological transition which the country is going through, in which there is an increase in the number of people who have chronic degenerative diseases and disabilities as a result of external causes, thus making home care necessary ${ }^{(2)}$.

Home care allows for new professional action, with workers going into patients' homes, which in turn allows teams to consider all aspects that affect user health and to implement effective interventions that meet patient needs. In home care, the figure of the caregiver is essential for successful treatment, as this person will carry out therapy and will be a reference for health care staff. ${ }^{(3)}$

Care of a family member results in various adaptations in family routines, particularly for caregivers. This job is very often done on a full-time basis and without the help of other people, which forces caregivers to give up work outside the home and allows less free time. This can result in negative impacts on personal and professional relationships. The exercise of care can affect caregivers' social networks, as contacts are less frequent. Nevertheless, the relationship with patients' relatives can be strengthened. ${ }^{(5)}$

The individual's social network can be defined as a group of people with whom they have some contact or social bond ${ }^{(6)}$. As for the term social support, it refers to qualitative aspects of the network, that is, the individual's degree of satisfaction with relationships ${ }^{(7)}$. Regarding disabled and dependent patients, social networks and social support are important as a means of providing support in facing disease or disability, as it helps families to fulfill physical, emotional, social and even financial needs of patients and caregivers ${ }^{(8-9)}$.

Individuals' first contacts with social networks are their families, those with whom they create emotional ties and build their own identity. However, families are systems that are constantly changing, and relationships within the family circle go through changes that are both emotional and structural. Crisis situations, such as a diagnosis of chronic disease of a family member or the presence of a disabled or dependent individual, can change relationship patterns. ${ }^{(5)}$

Identifying caregivers' social networks can contribute to the planning of team actions through an assessment of how ties that have been created affect patients' and caregivers' health. In a previous article, the relationship between social networks and social support was highlighted: caregivers who reported wider social networks noticed greater social support on material, emotional, affective, positive interaction and information dimensions ${ }^{(10)}$. In the present study, the objective is to analyze the social networks of family caregivers of disabled and dependent patients.

\section{METHOD}

This article is the result of a comprehensive crosssectional study of family caregivers's profiles and social support. The research was carried out and based on interviews made at home with family caregivers of disabled and dependent patients, cared for by a home care service (SAD) in the district council of Cidade Ademar, in the southern area of São Paulo city. Data collection was done between March and November 2011.

The study population consisted of 218 caregivers and 229 patients treated by the SAD and a convenience nonprobabilistic sample was used. One hundred and ten family caregivers of disabled and dependent patients participated in the study and they had been giving care for three months, without pay. Families in which the caregivers could not be identified were excluded.

In order to assess the sociodemographic features of caregivers, a questionnaire was applied, containing the following variables: gender, age, religion, length of family care, education, paid work, medical treatment, use of medicines for depression or tranquilizers, symptoms of pain and overload. The variables related to the patients were: gender, age, health problems and degree of dependence, and they were assessed with the Barthel scale, which was validated in Brazil in $2010^{(11)}$.

The Social Network Index ${ }^{(12)}$, an instrument that was adapted and validated in Brazil in 2003, was used to analyze social networks of caregivers. The questionnaire contains five questions: the first two concern the size of the social network (number of relatives and friends whom the caregiver trusts and can talk to about almost everything); the others concern their participation in neighborhood associations, sports or artistic activities, and NGOs, among others.

For the assessment of families, a genogram was used, which is a pictorial display of a person's family relationships that includes social, behavioral and cultural aspects, and it must involve at least three generations, with a record of relevant event dates. It is a useful tool that helps families perceive their dynamics, restructure behaviors and improve relationships ${ }^{(13)}$. In this study, the genogram was used to analyze the following aspects: structure and family circle, ties between family members, previous stable relationships, total of people living in the household, and health problems of other family members.

The study was approved by the Research Ethics Committee of the School of Nursing of the University of São Paulo (process 934/2010) and by the Municipal Health Secretariat (opinion 454/10). The interviews were started after the caregivers read, accepted and signed a Free and Informed Consent Form. All remaining ethics procedures were followed, in compliance with Resolution 196/96, in force at the time of data collection.
Social network of family caregivers of disabled and dependent patients Yamashita CH, Gaspar JC, Amendola F, Alvarenga MRM, Oliveira MAC 
Data were analyzed by Predictive Analysis Software (PASW), version 20.0. A Kolmogorov-Smirnov test was performed to check the normality of variables related to social network. A Mann-Whitney U Test was performed for the analysis of means of qualitative variables with two categories, and a Kruskall-Wallis test for three categories. Quantitative variables were analyzed through Spearman's rank correlation coefficient. Results were considered statistically significant when $\mathrm{p}<0.05$.

\section{RESULTS}

Out of 110 caregivers, 21 did not live in the same household as the patients. The average number of people who shared the household was 3.9 ( $S D=1.7$, median=4.0), varying from one to nine individuals.

The family structure of caregivers was defined as traditional in most cases (33.7\%), followed by extended families (30\%), single-parent (14.5\%), nuclear (9.1\%) and others (12.7\%). Most families were at the family stage titled raising children and moving on (51.8\%), followed by later stage (21\%), with young children (13.6\%) and at another life stage (13.6\%).

Most caregivers (60.9\%) mentioned a close relationship with some family members: with one or two (30\%), three to four $(19.1 \%)$, or five or more $(11.8 \%)$. Most relationships were close (49.1\%), but some were distant (20.9\%), harmonious (9.1\%) and conflicted (2.7\%).

The genogram showed that $29.1 \%$ of caregivers lived with people who also had health issues, in addition to disabled and dependent patients cared for by the SAD. Family members who also had a disease were mostly spouses $(11.8 \%)$, followed by children (10.9\%) and another kinship (14.5\%).

Issues related to social networks showed that the number of relatives the caregivers reported feeling free to talk to about almost everything varied from zero to 50 , with an average of 4.4 relatives $(S D=6.1$, median $=2.5$, mode $=1.0$ ). The average number of friends was 3.6 people $(S D=10.2$, median=1.0, mode=0), varying from zero to 100 .

The majority of caregivers did not attend social activities. To these questions, $11.8 \%$ reported they participate in team sports or artistic activities, $4.5 \%$ in neighborhood or employees association meetings, or union or party meetings, $7.3 \%$ in unpaid and volunteer work in NGOs and charity institutions or other activities.

Association tests were performed between the means of variables number of relatives/friends and those related to caregivers (gender, religion, education, paid work, medical treatment), patients (gender and degree of dependence) and families (relationship of the caregiver with family members, structure and family circle). However, the result was not statistically significant, as $p>0.05$ for all.
Table 1 - Distribution of family caregivers according to the characteristics of their social networks, Home Care Service (SAD) - São Paulo, SP, 2011.

\begin{tabular}{|c|c|c|}
\hline Variables & $\mathbf{N}$ & $\%$ \\
\hline \multicolumn{3}{|c|}{$\begin{array}{l}\text { Number of relatives whom they trust and can talk } \\
\text { to about almost everything }\end{array}$} \\
\hline $1-3$ & 64 & 58.1 \\
\hline $4-6$ & 20 & 18.2 \\
\hline $7-10$ & 9 & 8.2 \\
\hline$\geq 11$ & 10 & 9.1 \\
\hline None & 7 & 6.4 \\
\hline \multicolumn{3}{|c|}{$\begin{array}{l}\text { Number of friends whom they trust and can talk to } \\
\text { about almost everything }\end{array}$} \\
\hline $1-3$ & 58 & 52.7 \\
\hline $4-6$ & 12 & 10.9 \\
\hline $7-10$ & 5 & 4.5 \\
\hline$\geq 11$ & 6 & 5.5 \\
\hline None & 29 & 26.4 \\
\hline \multicolumn{3}{|c|}{ Participation in team sports or artistic activities } \\
\hline Once a week & 5 & 4.5 \\
\hline Two or three times a week & 5 & 4.5 \\
\hline Once a year & 1 & 0.9 \\
\hline A few times a year & 2 & 1.8 \\
\hline Does not participate & 97 & 88.2 \\
\hline \multicolumn{3}{|c|}{$\begin{array}{l}\text { Participation in neighborhood or employees asso- } \\
\text { ciation meetings, or union or party meetings }\end{array}$} \\
\hline Two or three times a week & 1 & 0.9 \\
\hline Once a year & 2 & 1.8 \\
\hline A few times a year & 2 & 1.8 \\
\hline Does not participate & 105 & 95.5 \\
\hline \multicolumn{3}{|c|}{$\begin{array}{l}\text { Participation in unpaid and volunteer work in } \\
\text { NGOs and charity institutions or other activities }\end{array}$} \\
\hline Once a week & 1 & 0.9 \\
\hline Two or three times a week & 2 & 1.8 \\
\hline Once a year & 2 & 1.8 \\
\hline A few times a year & 3 & 2.8 \\
\hline Does not participate & 102 & 92.7 \\
\hline Total & 110 & 100.0 \\
\hline
\end{tabular}

The variables symptoms of pain and partner showed a statistically significant difference regarding the average number of relatives caregivers reported they trust, with $p=0.003$ and $p=0.042$, respectively. Caregivers who reported pain in some part of their body had a greater average number of relatives whom they trust compared to those who did not report any pain. The same occurred with caregivers who had partners. Those who reported not using tranquilizers or medicines for depression showed a statistically significant difference between means regarding the variable number of friends, with $p=0.044$. Those who reported taking medicine for depression had a greater average number of friends compared to those who did not take any medicine (Table 2 ).

Once the Spearman's rank correlation test was performed, it was observed that the variables number of relatives to whom they provide care, caregiver's age, length of care, patient's age and diagnosis number did not present a statistically significant correlation. The variable total income had a statistically significant correlation 
with the number of relatives whom they trust $(r=0.197$; $p=0.039)$ and number of friends $(r=0.220 ; p=0.021)$. As for per capita income, there was only a correlation with the number of friends, with $r=0.198$ and $p=0.038$.

Table 2 - Comparison between social networks and variables related to family caregivers, Home Care Service (SAD) - São Paulo, SP, 2011.

\begin{tabular}{|c|c|c|c|c|c|c|}
\hline \multirow[t]{2}{*}{ Variables } & \multicolumn{3}{|c|}{$\begin{array}{l}\text { With how many relatives do you feel free } \\
\text { to talk about almost everything? }\end{array}$} & \multicolumn{3}{|c|}{$\begin{array}{l}\text { With how many friends do you feel free to } \\
\text { talk about almost everything? }\end{array}$} \\
\hline & Mean (SD $\left.{ }^{\dagger}\right)$ & Median & $P$ & Mean (SD) & Median & $p$ \\
\hline \multicolumn{7}{|c|}{ Use of medicines for depression or tranquilizers } \\
\hline No & $4.5(6.7)$ & 2.0 & \multirow{2}{*}{0.367} & $2.6(4.5)$ & 1.0 & \multirow{2}{*}{$0.044^{*}$} \\
\hline Yes & $3.8(3.3)$ & 3.0 & & $6.8(20.0)$ & 2.0 & \\
\hline \multicolumn{7}{|c|}{ Symptom of pain in some part of the body } \\
\hline No & $2.4(2.2)$ & 2.0 & \multirow{2}{*}{$0.003^{*}$} & $2.0(3.6)$ & 1.0 & \multirow{2}{*}{0.070} \\
\hline Yes & $5.3(7.1)$ & 3.0 & & $4.3(12.1)$ & 2.0 & \\
\hline \multicolumn{7}{|l|}{ Partner } \\
\hline No & $4.7(4.8)$ & 3.0 & \multirow{2}{*}{$0.042 *$} & $4.4(12.8)$ & 1.5 & \multirow{2}{*}{0.507} \\
\hline Yes & $3.8(7.6)$ & 2.0 & & $2.2(3.1)$ & 1.0 & \\
\hline
\end{tabular}

${ }^{\dagger} \mathrm{SD}=$ standard deviation

${ }^{*}$ statistically significant difference

\section{DISCUSSION}

As a result of historical and social changes in the Brazilian population, families' structure in Brazil has been changing and the traditional model, with parents and children, is no longer as prevalent as before. Nevertheless, in this study, the traditional family model prevailed, that is, the couple and biological children, followed by extended families, which are composed of parents, children and other members, related by blood or not.

The interactions among members in the family environment can help to meet the needs of each member, or result in various problems. It is essential that health teams understand how the family structure is designed and how members relate to each other, as this can affect the health-disease process ${ }^{(13)}$.

Family density, defined as the proportion of the total of individuals living in a household and the total of occupied households, also decreased in Brazil between 2001 and 2010 , from 3.8 to 3.3 residents per household ${ }^{(14)}$. In this study, the average number of residents was about four.

A larger number of family members does not ensure that caregivers have greater support, both for caring for disabled and dependent patients and meeting their own psychological and social needs. Lack of family support can be seen in other aspects of daily life, in the form of conflicts, health problems and lack of care for other family members, even children ${ }^{(15)}$.

Family lifetime concerns the stages that families go through over time, which can be predictable or not. In this study, most families were halfway in this lifetime (raising children and moving on), which is the stage when children leave home, new members arrive (son-in-law, daughterin-law, grandchildren), adjustments are made in marital life and a role reversal may occur, when children start to take care of parents who have become disabled and dependent as a result of chronic diseases ${ }^{(16)}$.
The presence of other members with some kind of health issue was also identified as a problem for families. If these people are not properly cared for, they may become disabled and dependent patients and also need treatment, which can overload the persons in charge of care. This can also result in more anxiety, stress and other problems for caregivers, with possible effects on care for patients ${ }^{(17)}$.

Regarding social networks of caregivers, they reported feeling more comfortable with and being able to trust an average of four relatives. A majority did not participate in activities outside the home. The most mentioned activities were team sports or artistic activities, at a frequency of one to three times a week.

Family, friends and care services that make up the social networks of caregivers are important elements of support that help to deal with the disease. Weak support results in increased distress for caregivers, and it gradually worsens as patients' health also worsens ${ }^{(8)}$.

The variables symptoms of pain and partner showed a statistically significant difference regarding means for the variable number of relatives whom the caregiver trusts and can talk to about almost everything. Caregivers who reported pain in some part of their body had a greater average number of relatives whom they trust compared to those who did not report any pain. As for those who had a partner, they had more relatives whom they trust, with a greater average than caregivers who had no partner. However, it is important to note that the interviewee could include spouses and children in the number of relatives whom they trust.

A study that assessed quality of life and overload of caregivers showed that those who had a partner had higher scores on quality of life. The authors also found that the worse the perception of social relations, the greater the overload. They observed a correlation between the number of people who lived in the household and the score in social relations ${ }^{(5)}$. Nevertheless, in this study, these associations were not statistically significant.
Social network of family caregivers of disabled and dependent patients Yamashita CH, Gaspar JC, Amendola F, Alvarenga MRM, Oliveira MAC 
The variable use of medicine for depression or tranquilizers had a statistically significant difference regarding the variable number of friends whom the caregiver trusts and can talk to about almost everything. Caregivers who reported making use of such drugs had a greater average number of friends than the interviewees who did not take these medicines.

Although the average number of friends is greater for caregivers who make use of medicines for depression, it is important to carefully assess the quality of these relations, as a greater number of relationships does not necessarily mean full support. Active social networks positively affects caregivers' health, and strengthening relationships can also contribute to improved quality of care ${ }^{(18)}$.

A statistically significant correlation was also observed between social networks and the income of families, suggesting that the higher the income, the larger the social network.

In a study on quality of life and perception of social support among elderly people at different levels of social vulnerability, the authors found a negative correlation between social vulnerability, perception of family support and quality of life, which suggested less support in more vulnerable social groups, with increased occurrence of emotional problems and conflicts between family members ${ }^{(19)}$.

Research carried out in São Paulo and Salvador found that the social networks of poorer individuals tend to be smaller and less varied regarding sociability. Over the years, the variability of these networks decreases even more, which gives increased importance to families. Education, income and age are variables associated with family-oriented social networks, which vary in the poorest group, with fewer connections between networks and sociability, including family ${ }^{(20)}$.

Regarding people with chronic diseases, social networks can contribute to better uptake to treatment. Families are one of entities responsible for support during disease, and very often, the most significant part for patients. Health professionals, especially nurses, are also an important element in the process and must identify existing social relationships and how these can be strengthened ${ }^{(21)}$.

Social networks and support contribute to improved physical and mental health of caregivers, which in turn contribute to minimized negative aspects of the disease, and they must act as promoters and protectors of health (22). Understanding caregivers' relationships, not only in a quantitative way but also how they occur, helps health professionals intervene in order to improve caregivers' health, thus improving care given to dependent patients as well as improving family dynamics.

\section{CONCLUSION}

The results of this study allowed us to find out that social networks of most family caregivers of disabled and dependent patients treated by the SAD were basically made up of relatives. Caregivers did not participate in activities outside home (sports, artistic activities, meetings, charity, among others).

For the variable with how many relatives do you feel free to talk about almost everything, caregivers who reported pain in some part of the body had a greater number of relatives whom they trust, as well as caregivers who had a partner.

Those who reported taking medicine for depression had a greater average number of friends compared to those who did not take any medicine, with an average of 6.8 people. The correlation analysis between social network and quantitative variables showed a statistically significant correlation between family total income and number of relatives and friends whom they trust.

Analyzing the social networks of caregivers allows health staff to identify the people who can contribute to care given to dependent patients, or represent a strong support when caregivers feel isolated and unable to rely on other people. It is important to identify people whom caregivers trust and encourage them to give caregivers the necessary support so they can live their own life.

The use of a genogram allowed interviewers and interviewees to be close, as caregivers could feel free to report possible conflicts or stronger ties. It also allowed for the participation of other family members, who contributed to build a graphic representation of the family, recalling family members who had health issues or died, and the relationship between members. In some cases, it was seen that caregivers were not able to clearly point out the relatives or friends with whom they had any kind of ties. In such cases, the justification was that they had too many relatives and friends. Nevertheless, this statement might not have corresponded to reality, as there were cases in which caregivers reported a total absence of social networks. Convenience sampling may also have limited the accuracy of the study as a result of difficulties encountered during data collection.

The contribution of this study to health professional practice in Primary Health Care (PHC), especially for nursing staff, was the identification of people whom caregivers may trust, consequently finding ways to strengthen these ties or minimize conflicts. The lack of opportunities to go out or participate in activities outside home makes caregivers look for family support. It is important to have other ties, such as friends or neighbors, so caregivers can feel they have support. The development of caregivers' groups in basic health units or in the region where the PHC services are be- 
ing provided can be an incentive for caregivers to participate in activities outside the home. This will enable them to meet other people who face similar situations, helping to reduce the distress caused by giving care.

\section{REFERENCES}

1. Brasil. Lei n. 10.424 , de 15 de abril de 2002. Acrescenta capítulo e artigo à Lei n. 8.080, de 19 de setembro de 1990 e dá outras providências, regulamentando a assistência domiciliar no Sistema Único de Saúde [Internet]. Brasília; 2002 [citado 2014 mar. 3]. Disponível em: http://www3. dataprev.gov.br/sislex/paginas/42/2002/10424.htm

2. Rehem TCMSB, Trad LAB. Assistência domiciliar em saúde: subsídios para um projeto de atenção básica brasileira. Ciên Saúde Coletiva. 2005;10 Supl:231-42.

3. Brasil. Ministério da Saúde; Secretaria de Atenção à Saúde, Departamento de Atenção Básica. Caderno de Atenção Domiciliar. Brasília; 2012.

4. São Paulo (Cidade). Secretaria Municipal de Saúde. Portaria n. 1.170 , de 13 de junho de 2008. Dispõe sobre a criação do Programa Hospitalar de Atendimento e Internação Domiciliar (PROHDOM) [Internet]. São Paulo; 2008 [citado 2014 mar. 3]. Disponível em: ftp://ftp.saude.sp.gov.br/ftpsessp/bibliote/ informe_eletronico/2008/iels.junho.08/iels109/M_PTSMS-1170_2008.pdf

5. Amendola F, Oliveira MAC, Alvarenga MRM. Influence of social support on the quality of life of family caregivers while caring for people with dependence. Rev Esc Enferm USP [Internet]. 2011 [cited 2014 Mar 03];45(4):884-9. Available from: http:// www.scielo.br/pdf/reeusp/v45n4/en_v45n4a13.pdf

6. Bowling A. Measuring health: a review of quality of life measurement scales. Maidenhead: Open University Press; 1997. Measuring social networks and social support; p. 91109.

7. Chor D, Griep RH, Lopes CS, Faerstein E. Medidas de rede e apoio social no Estudo Pró-Saúde: pré-testes e estudo piloto. Cad Saúde Pública. 2001;17(4):887-96.

8. Sanchez KO, Ferreira NMLA, Dupas G, Costa DB. Apoio social à família do paciente com câncer: identificando caminhos e direções. Rev Bras Enferm. 2010;63(2):290-9.

9. Brito ES, Rabinovich EP. Desarrumou tudo! O impacto do acidente vascular encefálico na família. Saúde Soc. 2008;17(2):153-69.
It is worth mentioning the use of the genogram as an important tool to be implemented in health care practice, as it identifies family dynamics and relationships between members and can contribute to planned interventions.

10. Yamashita $\mathrm{CH}$, Amendola F, Gaspar JC, Alvarenga MRM, Oliveira MAC. Association between social support and the profiles of family caregivers of patients with disability and dependence. Rev Esc Enferm USP [Internet. 2013 [cited 2014 Mar 03];47(6):1359-66. Available from: http://www.scielo.br/pdf/reeusp/v47n6/en_0080-6234reeusp-47-6-01359.pdf

11. Minosso JS, Amendola F, Alvarenga MRM, Oliveira MAC. Validação, no Brasil, do Índice de Barthel em idosos atendidos em ambulatórios. Acta Paul Enferm. 2010;23(2):218-23.

12. Griep RH, Chor D, Faerstein E, Lopes CS. Confiabilidade testereteste de aspectos da rede social no Estudo Pró-Saúde. Rev Saúde Pública. 2003;37(3):379-85.

13. Moimaz SAS, Fadel CB, Yarid SD, Diniz DG. Saúde da Família: o desafio de uma atenção coletiva. Ciên Saúde Coletiva. 2011;16(Supl 1):965-72.

14. Instituto Brasileiro de Geografia e Estatística (IBGE). Características da população e dos domicílios do Censo demográfico 2010 [Internet]. Rio de Janeiro; 2010 [citado 2014 mar. 3]. Disponível em: http://www.ibge.gov.br/home/ estatistica/populacao/censo2010/caracteristicas_da_ populacao/resultados_do_universo.pdf

15. Azeredo Z, Matos E. Grau de dependência em doentes que sofreram AVC. Rev Fac Med Lisb. 2003;8(4):255-65.

16. Carter B, McGoldrick M. As mudanças no ciclo de vida familiar: uma estrutura para a terapia familiar. $2 \underline{a}$ ed. Porto Alegre: Artes Médicas; 2001.

17. Pavarini SCl, Melo LC, Silva VM, Orlandi FS, Mendiondo MSZ, Filizola CLA, et al. Cuidando de idosos com Alzheimer: a vivência de cuidadores familiares. Rev Eletr Enferm [Internet] 2008;10(3):580-90. Disponível em: http://www. fen.ufg.br/fen_revista/v10/n3/pdf/v10n3a04.pdf

18. Silveira CL, Budó MLD, Silva FM, Beuter M, Schimith MD. Rede social das cuidadoras de familiares com doença crônica incapacitante no domicílio: implicações para a Enfermagem. Ciên Cuid Saúde. 2009;8(4):667-4.

19. Inouye K, Barham EJ, Pedrazzani ES, Pavarini SCI. Percepções de suporte familiar e qualidade de vida entre idosos. Psicol Reflex Crít. 2010;23(3):582-92. 
20. Marques ECL. Pobreza, sociabilidade e tipos de redes sociais em São Paulo e Salvador. Visioni Latino Am [Internet]. 2013 [citado 2014 mar. 3];(8):42-59. Disponível em: http://www. fflch.usp.br/centrodametropole/upload/aaa/273-Marques_ VisioniLA_8_2013.pdf

21. Tavares RS, Silva DMGV. A implicação do apoio social no viver de pessoas com hipertensão arterial. Rev Gaúcha Enferm. 2013;34(3):14-21.
22. Gonçalves TR, Pawlowski J, Bandeira DR, Piccinini CA. Avaliação de apoio social em estudos brasileiros: aspectos conceituais e instrumentos. Ciên Saúde Coletiva. 2011;16(3):1755-69. 